\title{
The Over-Emphasis on the Paying of Tithe and the Quest for Materialism among Religious Leaders: An Evaluation of the Biblical Teaching on Tithe
}

\author{
Philip Igbo \\ https://dx.doi.org/10.4314/jrhr.v13i1.9
}

\section{Abstract}

The concept of tithe and tithing is a biblical concept. Tithing was a hieratic tax instituted as a means to support the Levites who ministered at God's sanctuary. The Levites were to receive the tithes offered by Israel to Yahweh, because of the service they rendered at God's sanctuary, and because they had no landed inheritance. The tithe system was enacted as a hieratic tax meant to provide support for the priests and Levites "for the service that they perform at God's sanctuary (Num 18:21f). The tithes are voluntary; tithable things were products from the land or the herd. The tithe was basically for the support of the Levites who served at God's Sanctuary. However, it has been observed and sadly so, that some contemporary Church leaders, especially in Nigeria, seem to be laying undue emphasis on tithing to their own financial advantage. This study was, therefore, conceived as a re-evaluation of the concept of tithing and the context under which it developed. The goal is to use the findings of this reevaluation to mirror the over emphasis on tithing by contemporary Church leaders in Nigeria. Findings reveal that there is a deviation from the context under which tithing was developed to somewhat exploitation of unsuspecting members of the Church to the advantage of prosperity preachers in Nigeria. This raises the question as to 
Igbo: The Over-Emphasis on the Paying of Tithe and the Quest for Materialism among Religious Leaders: An Evaluationof the Biblical Teaching on Tithe

whether Christians of the contemporary era should still tithe since the context in which the tradition developed has changed.

Keywords: Tithe, hieratic tax, Aaronic Priest, Levites, Melchizedek

\section{Introduction}

The concept of tithing is of considerable importance in OT theology. As a custom, tithing was not peculiar to the Israelite people; it was also practiced among other ancient peoples. In Israel's worship, tithing became institutionalized during the Mosaic era. The purpose of the Levitical tithe system was to support the sanctuary and its personnel - the priests and the Levites. This practice continued up to the time of Jesus. At the time of Jesus, the Temple was still standing; the Levites and priests were still performing their functions and were still the 'legal' recipients of the tithe. Jesus did not overtly condemn the payment of tithes, but he denounced the Pharisees for paying assiduous attention to the paying of tithes and neglecting justice and mercy (Matt 23:23). Jesus did not insist on tithe as a means of sustenance for his apostles. The needs of the seventy disciples sent out on mission were supplied by those to whom they were sent, by freewill offerings (Matt 10:1-10; Mk 6:7-11; Lk 9:1-6). In the NT church, the emphasis on tithing is conspicuously absent. Although the ministers of the Gospel depend on the people for their sustenance, there was no indication that the NT endorsed the system of tithing as a principle for the sustenance of the ministers of the Gospel. It is not that paying tithes is no longer biblical, but the context has changed. Should ministers of the Church today still insist on tithes? This is the fundamental question that this article seeks to address. 


\section{Concept of Tithe in the OT}

The concept of tithing is of considerable importance in OT theology. The Hebrew word for tithe is $m a$ 'ăs'êr. The term, ma ‘ăs'ér, is related to the Hebrew verb 'ăśar which means "to give the tenth of," "to give a tithe", referring to the standard ten percent tax on grain, grapes, and flocks by a king in the ANE. The practice of tithing was observed in secular as well as sacred contexts. In the secular world, tithing was a kind of tax levied by the local king (or other rulers) on his subjects (Vinson, 1994).

Tithing as an act of contributing ten percent of one's earnings for the support of religion was an ancient custom in many countries of the ANE (Allison, 1994). This practice was also observed in Biblical times. In the OT, offerings, and paying of the tithes were an important part of Jewish religious worship. The paying of tithes to God was recognized as a duty before the time of Moses.

\section{Abraham and the Tithe (Gen 14:16-20)}

The custom of giving a $10^{\text {th }}$ part of the products of the land and of the spoils of war to priests and kings is a very ancient one (cf. 1 Macc 10:31; 11:35; 1 Sam 8:15,17). This custom existed long before the institution of the Mosaic Law as shown by Gen 14:17-20 (compare Heb 7:4) and Gen 28:22. The paying of tithes was not peculiar to the Israelite people. It was practiced among other ancient peoples. Cuneiform tablets contain frequent references to tithing in ancient Chaldea and Ugarit in Syria. The great temples of Babylonia were largely supported by the tithe, which was levied on princes and peasants alike. The tithe to the Temple is also known to have been in effect in Punic culture (i.e., at Carthage) and was, in fact, part of the 
"basic taxation system of the city". Tithing in ancient cultures was associated with a sacrificial system and offerings to a god or gods (Eichrodt, 1987).

The word "tithe" (Heb ma 'ăśêr; Grk: dekatos - the tenth part) first appeared in the OT Canon in Gen 14:20. Abraham, victorious over the armies of the kings, had rescued his nephew Lot and brought back all the goods and captives previously taken by the enemies. He was met by Melchizedek, "king of Salem" (melek šâlèm, Gen 14:18a) and "priest of God Most High" (ǩōhēn le'ēl-'elyôn, Gen 14:18b). Melchizedek honoured the victorious Abraham with a meal and blessed him in the name of God Most High, the Creator, and blessed Abraham's God for delivering Abraham from his enemies. Abraham recognized Melchizedek's status as a true priest of the true God by giving him "a tenth of everything" he had brought back from battle (Gen 14:20; Heb 7:6). The giving of a tenth of his spoils of war to Melchizedek implies that Abraham recognized the legitimacy of Melchizedek's priesthood.

Abraham's tithe to Melchizedek appears to be voluntary. Note that Abraham "gave" (nātan) as opposed to "paying" a tithe. In giving the tithe to Melchizedek the bible does not say Abraham was obeying a set law prescribing that a tithe be given; nor was it said that God had commanded him to pay any tithe. Abraham's action in giving a tithe to Melchizedek was not in accord with any clear law of tithing then written or unwritten. Abraham may have been responding, in part, to customs within the religious culture of his day. Tithing to both God and country was well known in the ANE. The mention of Abraham's giving of his tithe to Melchizedek may be a way of legitimizing the 
practice in Israel by rooting them in the story of Abraham (cf. Jacob's vow of a tithe in Gen 28:22) (Fretheim, 1994).

\section{Jacob and the Tithe (Gen 28:20-22)}

Apart from Gen 14:20, which we have discussed above, Gen 28:22 is the only other place in the book of Genesis where the practice of tithing is referred to. In this passage, Jacob vowed to give to God a tenth of all that he (Yahweh) would give him if he (Yahweh) would protect and provide for him on his journey away from his father's house (Gen 28:22). The Bible does not say that Jacob was obeying a set law prescribing the giving of a tenth. Jacob promised God a tenth of "all you will give me," but only if (v 20) God would be with him and blesses him.

Apart from Gen 14:20 and Gen 28:22 where the word "tithe" was used in the Abraham and Jacob stories, there is no other reference to the tithe until the Mosaic time, when the law on tithe was introduced in ancient Israel (Lev 27:30-34). But there is abundant evidence that offerings and sacrifices were an established part of the Patriarchal religious system. Patriarchal sacrifices, offerings, and voluntary tithes were expressions of the heart and an act of gratitude to God for blessings received. These offerings include the offering of the first fruits, firstlings, and other offerings (Abel: Gen 4:4,5; Noah: 8:20; Abraham: 12:7,8; 13:3,4,18; 22:2ff). Apart from Gen 14:16-20 and 28:20-22, there are three main passages in the Pentateuch that talk about tithes - Lev 27:30-33; Num 18:21-32; Deut 12:5, 6, 11, 18. 
Igbo: The Over-Emphasis on the Paying of Tithe and the Quest for Materialism among Religious Leaders: An Evaluationof the Biblical Teaching on Tithe

\section{Tithe in the Mosaic Era}

Apart from Gen 14:16-20 and 28:20-22, there are three main passages in the Pentateuch that talk about tithes - Lev 27:30-33; Num 18:21-32; Deut 12:5,6,11,18.

\section{Tithe in Lev 27:30-33}

There is no noticeable reference to tithe in the Book of Exodus. The Book of the Covenant (Exod 20-22-23:33), which most scholars consider as the oldest law code in the Torah, does not mention tithe (Vinson, 1994). However, the Book of Exodus requires that sacrifices and offerings be brought to the house of the Lord (Exod 20:24; 24:5). This suggests that the practice of tithing is not precluded.

The first Mosaic Law on tithe is contained in Lev 27:30-33, after the establishment of the tabernacle. Lev 27:30-33 specifies two types of tithes that should be offered: a tenth of all the agricultural produce, i.e., of the crops, of the fruit of the tree, e.g., oil and wine, and a tenth of the flocks or herds (compare Deut 14:22,23; 2 Chron 31:5-6). The

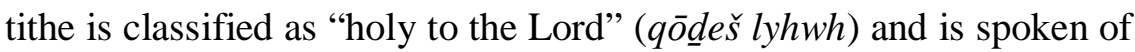
as belonging to the Lord or as something owed to the Lord (Hartley, 1992).The Book of Leviticus ends with the closing formula in 27:34, referring to all the commands that God had given on Mount Sinai. This refers to the total legislation covering the contents of Leviticus (Kasper, Jr, 1994).

\section{Tithes in Num 18:21-32}

Lev 27:30-34 prescribes that tithes should be made to the Lord; Num 18:21-32 specifies that the tithe must be paid to the Levites. The purpose of the Levitical tithe system, as Num 18:21-32 indicates, was 
to support the sanctuary and its personnel - the priests and the Levites. In biblical times, tithable items consisted of agricultural produce i.e., tithing on grain, fruits, oil, wine, livestock (Num 18:27), which coincides with the seed of the land and fruit of the trees in Lev 27.

The tithe was never a votive offering (i.e., voluntarily vowed and subsequently offered to the Lord (Gen 14 and 28 are exceptions). In Num 18:21-32, it is laid down that the tithe (i.e., tithing on grain, fruits, oil, wine, livestock) must be paid to the Levites, the nonpriestly temple servants from the tribe of Levi. Having been chosen by Yahweh to serve at the Lord's sanctuary, the Levites have been elevated to a status that sets them apart from the rest of the tribes of Israel. Though the Levites were assigned duties at the Tabernacle of the Lord, they were non-priests and were forbidden at the pain of death to gain access to the altar (Num 18:2-3), but presumably, they pronounced blessing in the Lord's name elsewhere in the sacred precinct (Milgrom, 1978). The Levites were to receive the tithes offered by Israel to Yahweh, because they were assigned priestly functions i.e., because of the service they render in the tent of meeting (Num 18:21.24; Neh 10:32-39; and Heb 7:5-10), and because they had no landed inheritance. The Lord explicitly said to Aaron: "You shall have no allotment in their land, nor shall you have any share among them; I am your share and your possession among the Israelites" (Num 18:20). This leads naturally and immediately to the Levitical tithe. J. M. Baumgarten (1984) refers to the tithe as "hieratic tax" meant to provide support for the priests and Levites. R. K. Duke (1987: 197) refers to the economic status of the Levites in the Israelite society as a "dependent status." Because of their "socio-economic status" a "legislation was enacted so that sustenance would be 
provided for them." Num 18:21f explicitly makes it clear that the tithes were given to the Levites "for the service that they perform, the service in the tent of meeting..." The tithes are voluntary. Tithes represented one-tenth of a person's produce. This portion was given to the Levites. Just as other Israelites were expected to pay their tithes to the Levites, so the Levites who receive the tithes were in turn required to give a tithe of all they received from the Israelites to the Aaronic priest. This is known as a tithe of the tithe (Num 18:28-30; Padzan, 2001; Ajah, 2013).

The tithe of tithe that the Levites gave to the priests was only part of the system of support for the priests; the offerings from the altar also went to the Aaronic priests (Num 18:8). The tithe of tithes that the priests received from the Levites was not the only offerings that the priests received for their upkeep. The priests received their emoluments from several sources: sin-offerings and reparationofferings; a considerable part of the cereal offerings, the shewbread, the breast and right shoulder of thank-offerings, the skins of the animals sacrificed as burnt-offerings, the first-fruits of grain and other produce of the earth, the firstborn of cattle (or the money equivalent), the five shekels ransom money for human firstborn, part of the proceeds of sheep-shearing and a large number of occasional dues.

The general principle in Num 18 is that, since neither the priests nor the Levites (i.e., all from the tribe of Levi) had a regular inheritance like the other tribes, therefore, they all needed support through the tribal system of tithes (focused on provision for the Levites, Num 18:21-24) and offerings (focused on provision for the priests, Num 18:8-20). The tithe was to be their primary means of subsistence so that they could serve the Lord without distraction. It 
may be noted that a greater number of the Levites did not perform services in the temple, probably because there was not enough work for everyone during non-festival times. For the rest of the time, they lived in their hometowns (1Chron 24:1-19). All priests served during the festival seasons. This system was still in place in Christ's day (Lk $1: 5-9)$.

As earlier said, when the allotment of the portions of the Holy Land was made to the tribes of Israel, no inheritance was allotted to the Levites. However, when the Bible says that the Levites "have no inheritance among the Israelites" (Num 18:24), it does not mean that they did not have homes, cities, and pasturage. Josh 20:2-3 makes it clear that during the allotment of the Land of Promise, cities of refuge were assigned to the Levites, where persons who commit crimes without intent or by mistake may flee. Num 35:1-8 indicates that forty-eight towns were given to the Levites to live in, and as their pasture lands for their cattle, their livestock, and their animals, to enable them to earn their living, without having to depend solely on the offerings and tithes they were given. The towns "include the six cities of refuge, where a slayer might flee. These Levitical cities were theirs in perpetuity (Lev 25:32-34).

Apart from the priestly functions, the Levites performed some other duties within the nation of Israel. They also functioned as teachers (Deut 24:8; 33:10; 2 Chron 35:3; Neh 8:7); Judges (Deut 17:8-9; 21:5; 1 Chron 23:4; 2 Chron 19:8); singers and musicians (1Chron 25:1-31; 2 Chron 5:12; 34:12); writers and librarians (1Chron 2:55; 2 Chron 34:13); architects and builders (2 Chron 34:813) etc. When the Levites were on duty at God's sanctuary, they received not the whole of the Israelites' tithes, but only a portion of 
the tithes (Num 18:24). The rest of the tithes of the Israelites was eaten by them before God at the central sanctuary (Deut 14:22-27). Deut 14:27 tells us that "the Levites resident in your towns" shared the tithes with the Israelite households.

\section{Deuteronomy 12:5-7,11-12,18; 14:22-29}

In Deut 12:5,6,11,18 (compare Amos 4:4), it is said that the tithe is to be brought "in the place that he (God) will choose as a dwelling for his name," i.e., to the central sanctuary. Both the Deuteronomic (Deut 14:22-29; 26:12-15) and the Priestly (Lev 27:30-33; Num 18:21-32) codes prescribe that tithes and offerings should be brought yearly to the central sanctuary. With the Jerusalem Temple built by Solomon, this central place of worship, without any equivocation, became Jerusalem. Deut 12:7,12,18 and Deut 14:23specify that the tithe should be eaten (as a sacred meal) "in the presence of the Lord . . . at the place he will choose as a dwelling for his Name." Properly understood, these regulations on tithe could have been a workable and economically reasonable means of providing for the priests, Levites, and tabernacle/temple worship system in either the pre-exilic or postexilic periods of OT history. Whether or not the ten percent rule was meant to be followed exactly, however, is open to question.

The tithe offered to the Levites/priests was considered a "sacred portion" (haqqōdeř, Deut 26:13). It was given to the Lord in the sense that it was given to the people to whom the Lord had assigned it: the Levites, the poor, and the disadvantaged (cf. Num 18:8, 24). 


\section{Tithes in the Prophetic Books}

There are several references to tithe in the Prophetic Literature. The most outstanding of these is Mal 3:7-12. Malachi criticized the postexilic community for failing to offer their tithes as prescribed by the law (Mal 3:7-12; cf Lev 27:30f; Num 18:21-32).

\section{Malachi 3:7-12}

Malachi regards the failure to pay tithe as a direct offence against God. He charges the people with "robbing God" by withholding tithes and offerings. What the prophet is saying in effect is: the tithe belongs to God; to withhold one's tithe is to rob God. Malachi attributed the failure of their crops to the failure to pay their tithes (Carstensen, 1971). Later, Nehemiah would interpret the failure to pay tithes as neglect of the Temple (Neh 10:40; 13:11; Igbo, 2020). Malachi's indictment of the people for failure to pay their tithes (Mal 3:8) is followed the positive exhortation (Mal 3:10): "Bring the full tithe (kol-hamma 'ăśer) into the storehouse." Malachi seems to say here that the observance of the law on tithes is a pre-condition for God's blessings (Pazdan, 2001; Onyenali, 2017).

In Mal 3:10-12, Malachi assures the people that faithfulness in the payment of the tithes will be rewarded. God will "open the windows of heaven" and "pour down" for them an overflowing blessing - abundant rainfall - and rebuke the devourer (the locusts) if they are faithful to the payment of their tithes $(3: 10 \mathrm{~b})$. Such blessing will result in surplus harvests. The prosperity of the Jewish nation will be a witness to all nations of the blessings of the obedience to Yahweh (Carstensen, 1971). 


\section{Amos and the Critique of the Tithe System}

The prophet Amos raised his voice against a religiosity that is not accompanied by a life of justice. Amos sarcastically asks the Israelites to bring their tithes every three days: "Come to Bethel - and transgress; to Gilgal- and multiply transgression; bring your sacrifices every morning, your tithes every three days (Amos 4:4). This is a protest against a formalistic practice of religion that is unaccompanied by ethical behaviour and mercy towards the poor and the less privileged. Amos does not as such condemn the offering of tithes or any other offering, but he emphasizes that what pleases God more is a righteous life and applying justice to the poor and the less privileged.

\section{Tithes in Jesus' Day}

It has already been emphasized that the tithe system was instituted in the OT as a "hieratic tax" meant to provide support for the support of the ministers of the Sanctuary. At the time of Jesus, the Temple was still standing; the Levites and priests were still performing their functions and were still the 'legal' recipients of the agricultural tithe. The Levitical law required only crops and animals to be tithed (Deut 24:22), but Pharisees, according to Talmudic law, tithed even on their garden herbs. The Pharisee could, therefore, make the claim, "I give a tenth of all my income" (Lk 18:12), not that the Law demanded this, but rather that the oral interpretations did. Jesus did not overtly condemn the Pharisees for their payment of tithes, but he denounced them for paying assiduous attention to the paying of tithes - tithing "mint, dill, and cummin," and neglecting "the weightier matters of the law: justice and mercy and faith" (Matt 23:23). 
Jesus did not insist on tithe as a means of sustenance for his apostles. The needs of the seventy disciples sent out on mission were supplied by those to whom they were sent, by freewill offerings (Matt 10:1-10; Mk 6:7-11; Lk 9:1-6). The apostles were not to expect payment for their services, they were to have their needs met by those who responded to their message. The ministry of the Church is something which the disciples received freely (dorean), therefore, they are not to profit from the Gospel, even though their basic needs are to be met. Sustenance, not profit, is the rightful expectation of those who preach the Gospel (cf 1 Cor 9: 18; Hagner, 1993; Igbo, 2009). This is the basis in Jesus' instruction to his disciples, "You received without payment; give without payment" (Matt 10:8b). Jesus demands of his disciples unconditional unself-seeking (Oepke, 1965; Igbo, 2009).

\section{Tithes in the Early Church}

At the beginning of the Church, the priest and Levites were still performing their duties at the Temple and still receiving the tithes of the Israelites. With the destruction of the Jerusalem Temple in A.D. 70 , the payment of the tithe stopped. Since the Temple was no more in existence, the Temple cult also came to a halt. Therefore, the need to provide for and sustain the Levites in their temple duties ceased. In the NT church, the emphasis on tithing is conspicuously absent. Although the NT church began forty years earlier than the destruction of the Temple, there is no indication that the early church made any claims on the Levitical tithes or imposed any tithing obligations upon its followers. There is no indication in the NT that the early church used the tithing system to support its ministry (Dietlein, 1967). The NT church neither collected nor imposed tithes. The NT church, nevertheless, specified the principles and patterns for sustaining the ministers of the Gospel. The early church and its work were financed 
by freewill donations, the amount depending on one's level of prosperity (1 Cor 16:1-3; 1 Cor 9:6-18; 2 Cor 8:1-4; Rom 15:25-28).

Among the earliest church fathers, tithing was not considered to be an appropriate standard for Christian giving. Irenaeus, for example, "considered tithing to be a Jewish law, not required of Christians, for Christians had received 'liberty' and should consequently give without external constraint".

In the OT, the payment of tithes was enjoined for the maintenance of religion. The payment of tithes was also implied in the NT (cf. Matt 10:10; 23:23; 1 Cor 9:7). After Jesus' sacrificial death, there was, therefore, a change in the practical application of this Law, though the principles of sacrifice and offering are eternal. This purpose of maintaining the Levites was no longer needed. This does not mean that the early church did not recognize the need for supporting the religious leaders and ministers of the Gospel. Although the ministers of the Gospel depend on the people for their sustenance, there was no indication that the early church endorsed the system of tithing. The ecclesiastical authority in the early church recognized that there were other ways of supporting the ministers of the word, apart from the tithe system.

\section{Paul: His Teaching on Financial Matters}

Paul nowhere made claims to any tithes (Eph 2:20; Is 8:20; 1Tim $3: 15)$. Nevertheless, Paul insisted on the support of those who preach the Gospel. Paul had stated that "those who proclaim the Gospel should get their living by the Gospel" (1 Cor 9:14). Paul also stressed the need to give freely (Rom 12:8) and "voluntary", not as something 
"forced" (Philem 14). Each one should give as he decides in his heart, not grudgingly or under compulsion (2 Cor 9:6-8).

In Phil 4:14-19, Paul acknowledges the aid he received in Thessalonica from the Philippians. Paul praises the Philippians for their fine examples of voluntary giving and refers to their donation as an acceptable sacrifice, well-pleasing to God.

\section{Hebrews 7:1-10}

One of the passages of the NT which gives much space to the discourse on tithe is the Letter to the Hebrews. The basis of the discourse on tithe in Heb 7:1-10 is the comparison between the priesthood of Melchizedek to whom Abraham gave the tithe (Gen 14:20) and the priesthood of Jesus. The priesthood of Melchizedek is presented as the background for the high priesthood of Jesus. In Gen 14:18, Melchizedek is referred to as "priest of God Most High" (hiereus tou theou tou uphistou).

In Heb 7:3-4, the character of Melchizedek's priesthood is stressed. Melchizedek is portrayed as a supra-human figure whose priesthood is a type of the priesthood of Christ. Melchizedek's line of priesthood is significant because it has no ancestry (without father, apator), without mother (ametor), without genealogy (agenealogetos), "having neither beginning of days nor end of life, but resembling the Son of God, he remains a priest forever" (Heb 7:3). This is in contrast with the Levitical priesthood, where a recorded line of descent was required for accession to the priestly office (Exod 28:1; Lev 21:13-15; Num 3:10; 18:1; Ezra 2:61-63; Neh 7:63-65; Lane, 1991). In Heb 7:9-10, Melchizedek's priesthood is described as permanent or unchangeable (aparabatos, Heb 7:24), and 
is therefore, a heavenly one. Christ's priesthood is greater than that of the Aaronic priesthood. The Aaronic priesthood, with its entire support system, was to "offer sacrifice for his own sins as well as for those of the people" (Heb 5:1-4). Christ (our Priest) is without sin.

The author of the Letter to the Hebrews made a distinction between the Aaronic priesthood and the priesthood of Christ. The former is temporal, the latter spiritual; the former offered sacrifices repeatedly (for his sins and the sins of his people) in contrast to the one sacrifice of the latter (offered once for the expiation of the sins of the world); the sacrifice of the former is imperfect compared to the perfect offering of the latter (cf. Gal 4:24-26). The author describes the priesthood of Christ as one which is not according to an earthly law; neither is it "through a legal requirement concerning physical descent," rather Christ's priesthood is "through the power of an indestructible life or endless life; it is eternal (Heb 7:16).

In Heb 7:18-19, the author introduces the subject of "tithe" which Abraham paid to Melchizedek to illustrate the supremacy of Christ's priesthood over the Levitical priesthood. The author makes it clear that Abraham gave the tithe (a tenth of the spoils of war) to Melchizedek because he recognized the superior character of Melchizedek's priesthood (Heb 7:2, 4, 6). The Levitical priest received tithes for their services in the priestly office (Num 18:21-24). These priests collected tithes on the ground of an ordinance in the Mosaic Law (cf. Lev 27:30-33; Num 18:21-32; Deut 12:5-7, 11-12, 18; 14:22-29). As a priest, Christ resembles (Greek: homoiotes: likeness) Melchizedek (Heb 7:15). Christ's priesthood is of the order of Melchizedek, not according to the order of Aaron (Heb 7:11). Having made this distinction, the author stresses that the Levitical 
priesthood has been superseded by the High Priesthood of Christ because Christ's priesthood is of a higher character (Heb 7:11); it is permanent (aparabatos) and eternal (aiōnos) and (Heb 7:24). Therefore, ministers of the Church are not bound by the Mosaic law on tithes like the Levitical priests of ancient Judaism.

\section{Emphasis on Tithes in Today's Church}

The practice of tithe in the OT was based on divine law. The "goal" of tithing is for the support of the ministers of the Temple. Today, there is a disagreement on whether tithing should continue in the Church or not. While some scholars, like E. N. Omorogbe (2019) argue that tithing remains valid in the contemporary church, others reject it as completely invalid. One of the major arguments against tithing in the contemporary church is that the NT does not mention tithing as a principle for the NT church. The tithe was but one segment of the offertory system of ancient Israel. There is scriptural invalidity in claims that Christians today are bound by a tithing regime; the standard for us today is to give bountifully from a cheerful and willing heart.

It must be noted that tithing was a Mosaic legislation applying to the Israelites. If tithing was not a universal command, then it needs not to apply to Christians or at least should not be enforced on Christians. Today, tithe-advocates make many, including the poor, feel guilty or feel they are robbing God by not paying tithes. We must bear in mind that the original purpose of the tithe legislation was to provide support for the Levites, the priests, and the poor of the land. Is it right to press people to tithe when they cannot afford their basic necessities? Does God expect the poor to be deprived of their basic necessities? 
In the Church today, the majority of those who tithe are the poor who are enticed by preachers to tithe with the hope that God will bless them materially. Often tithe-advocates cite Mal 3:10 in order entice the poor people to pay tithe: "Bring the full tithe into the storehouse, so that there may be food in my house, and thus put me to the test, says the Lord of hosts; see if I will not open the windows of heaven for you and pour down for you an overflowing blessing" (Mal 3:10). However, there are millions of tithing Christians who have tithed for generations without escaping poverty, while these prosperity preachers and "men of God" who benefit from the tithes become wealthy. There is no evidence that the vast majority of poor tithe-payers are ever blessed financially merely because they tithe (Kelly, 2015).

Today, there are many ways the Church's ministers are maintained. It is not that paying tithes is no longer biblical, but we do not have to over-emphasize it, since the ministers of the Gospel are maintained in several other ways other than the tithe. Today, many preachers even hinge going to heaven on the payment or non-payment of tithes. People are pressured to pay their tithes to the pastor or man of God, who uses the tithe money for luxurious living. It seems many of the church leaders and preachers are taking advantage of the poor with their over-emphasis on the tithe. If we must insist on the biblical legislation on tithe, then we must also insist that the tithe be restricted to the things prescribed by the Jewish Bible, i.e., agricultural products and livestock. Tithing in the Mosaic law was only from crops and cattle from the land of Israel, not on money (Lev 27:30, 32; Num 18:27-28; Deut 12:17; 14:22-23; 26:12; 2 Chron 31:5-6; Neh 10:37; 13:5; Mal 3:10-11; Matt 23:23; Lk 11:42). In the NT period, artisans, fishermen, 
and tradesmen did not pay tithes on their income, and Jews who lived outside of Israel did not pay tithes on anything (Kelly, 2015).

\section{Conclusion}

In the OT, offerings, and paying of the tithes were an important part of Jewish religious worship. Tithing, as a hieratic tax meant for the support of the ministers of the Lord's sanctuary, was a Mosaic prescription. The ecclesiastical authority in the early church recognized that there were other ways of supporting the ministers of the word, apart from the tithe system. The NT church neither collected nor imposed tithes. While the practice of tithe has not been condemned, it should not be enforced on believers by the ministers. It must be noted that tithing was a Mosaic legislation applying to the Israelites. The original purpose of the tithe legislation was to provide support for the Levites and the priests. There are several ways the Church's ministers in contemporary time are maintained. If tithing was not a universal command, then it needs not apply to Christians or at least should not be enforced on the Christian faithful by religious leaders.

\section{References}

Ajah, M. (2013). The Significance of Pentateuchal Tithing as a Legal Instruction for the 21st Century Reader. The Asbury Journal. Volume 68, Number.2. Pp. 106-119. Accessed on April 6, 2021 from asburyseminary.edu.

Allison, D. E. (1994). "Tithe," in Luttherworth Dictionary of the

Bible. W. E. Mills (Ed).Cambridge: The Lutterworth Press.

Averbeck, R. E. "ma ăśér, tithe," in Dictionary of Theology and

Exegesis, CD Rom Edition. 
Igbo: The Over-Emphasis on the Paying of Tithe and the Quest for Materialism among Religious Leaders: An Evaluationof the Biblical Teaching on Tithe

Baumgarten, J. M. (1994). "On the Non-Literal Use of "ma 'ăśér/Dekatē." Journal of Biblical Literature. Volume 103, Number 2.(pp.245-261).

Carstensen, R. N. (1971). The Book of Malachi, in The Minor Prophets and the Apocrypha, Volume 5, C. M. Laymon (Ed), Nashville: Abingdon.

Carstensen, R. N. The Book of Malachi, The Interpreter's One Volume Commentary on the Bible, Nashville: Abingdon, 1971.

Dietlein, D. (1967). "Tithes," In New Catholic

Encyclopedia. Volume14. New York: McGraw-Hill.

Duke, R. K. (1987). "The Portion of the Levite: Another Reading of Deuteronomy 18:6-8," Journal of Biblical Literature. Volume 106, Number 2. Pp.193-201.

Eichrodt, W. (1987). Theology of the Old Testament, vol. 1. London: SCM.

Fretheim, T. E. (1994). The Book of Genesis. New Interpreter's Bible. Volume 1. L. E. Keck (Ed). Nashville: Abingdon.

Hagner, D. A. (1993). Matthew 1-13, Word Biblical Commentary.

Volume 33A Nashville: Thomas Nelson Pub.

Hartley, J. E. (1992). Leviticus. Word Biblical Commentary. Volume 4, Dallas: Word Books.

Igbo, P. (2020). Introduction to the OT Books and Pseudepigrapha. Enugu: San Press.

Igbo, P. (2009). "The New Generation Healing Ministries and the Mission of the Church," African Journal of Contextual Theology, Volume 1. Pp.63-74.

Kasper, W. C. Jr., (1994). The Book of Leviticus, New Interpreter's Bible. Volume 1. L. E. Keck (Ed). Nashville: Abingdon.

Kelly, R. E. (2015). Tithing is not a Christian doctrine. Accessed on January 31, 2015, from http://www.tithing-russkelly.com.

Lane, W. L. (1991). Hebrew 1-8. Word Biblical Commentary. Volume47 A. Columbia: Thomas Nelson. 
Milgrom, J. (1978). "Studies in the Temple Scroll," Journal of Biblical Literature. Volume 97, Number 4. Pp.501-523.

Oepke, A. (1965). iaomai. Theological Dictionary of the New Testament, Volume 3. G. Kille (Ed). Grand Rapids.

Omorogbe, E. N. (2019). "A Re-Examination of tithe in the Light of the 1983 Code of Canon Law." The Nigerian Journal of Theology. Volume 33.Pp.26-63.

Onyenali, R. (2017). Paying of Tithe: The History Behind the Theology. Enugu: Claretian Publications.

Pazdan, M. M. (2001). Joel, Obadiah, Haggai, Zechariah, Malachi. Collegeville Bible Commentary, Old Testament, vol. 17. Bandra: St Pauls.

Solyma, H. K. O. A History of Tithing from the Bible,www.alphalink.com.

Vinson, R. B. (1994). "Tithe," in Luttherworth Dictionary of the Bible, W. E. Mills (Ed),Cambridge: The Lutterworth Press.

Philip Igbo (CMF, PhD) is a lecturer in Spiritan International School of Theology, Attakwu, Enugu, Nigeria. 